\title{
Novel Composite Films Based on Acrylic Fibers Waste / Nano-Chitosan for Congo red Adsorption
}

salah Selim ( $\nabla$ salah@eaeat.edu.eg )

Egyptian Academy for Engineering and Advanced Technology https://orcid.org/0000-0002-8944-768X

Gamal A. Meligi

Science Faculty, Ain Shams University

Ahmed E. Abdelhamid

NRC: National Research Centre

Mahmoud A. Mabrouk

Egyptian Academy for Engineering and Advanced Technology

Ahmed I. Hussain

NRC: National Research Centre

\section{Research Article}

Keywords: Acrylic fiber, Nanochitosan, Composite film, Water treatment, Congo red

Posted Date: October 25th, 2021

DOI: https://doi.org/10.21203/rs.3.rs-1003890/v1

License: (c) (i) This work is licensed under a Creative Commons Attribution 4.0 International License.

Read Full License 


\title{
Novel Composite Films Based on Acrylic Fibers Waste / Nano-Chitosan for
}

\section{Congo red Adsorption}

\author{
Salah E. Selim ${ }^{\text {a* }}$, Gamal A. Meligi ${ }^{\mathrm{b}}$, Ahmed E. Abdelhamid ${ }^{\mathrm{c}}$, Mahmoud A. Mabrouk ${ }^{\mathrm{a}}$ \\ and Ahmed I.Hussain ${ }^{c}$ \\ a Egyptian Academy of Engineering and Advanced Technology Affiliated to Ministry \\ of Military Production \\ ${ }^{\mathrm{b}}$ Chemistry Department, Faculty of Science, Ain Sham University. \\ c Polymer and Pigments Department, National Research Center, 33 El-Buhouth St., \\ Dokki, Cairo, 12622, Egypt. \\ *Corresponding author email: salah@eaeat.edu.eg
}

\section{Abstract:}

Dyes are a form of pollutant that has been dumped into water sources by a variety of industries, causing environmental and human health problems. As a result, the current research focuses on recycling acrylic fibers waste combined with nano-chitosan for use as an adsorbent to remove Congo red (CR) from wastewater. Acrylic fibers (AF) waste were mixed with nano-chitosan ( $\mathrm{NCh}$ ) with different ratios and converted into films by using phase inversion method to prepare two nanocomposites films coded, AF-NCh and AF-NCh-Epichlorohydrin. The nanocomposites films have been characterized using; Fourier transform infrared, scanning electron microscope, surface area, and thermal analysis. The results revealed successful incorporation of NCh into AF matrix with highly porous structure. Adsorption studies were carried out to get the optimum condition for CR remediation process. Different parameters were employed such as, CR concentrations, adsorbent dose, effect of time and $\mathrm{pH}$. Langmuir, Freundlich isotherms and kinetic studies evaluations were applied. Results declared that, the maximum adsorption capacities of AF-NCh and AF-NCh-Epichlorohydrin were 166.6 and 232.5 $\mathrm{mg} / \mathrm{g}$ respectively. The adsorption isotherm and kinetic mechanism obey Langmuir and pseudo second order models. Regeneration of the synthesized composite films were studied for five cycles and showed relative stable reading with high efficiency.

Keywords: Acrylic fiber; Nanochitosan; Composite film; Water treatment; Congo red 


\section{1- Introduction:}

Synthetic dyes are used in a variety of industries, including leather, paper, and textiles, because of their color-giving properties. Each year, it is estimated that 700,000 tons of various colorants are produced from approximately 100,000 commercially available dyes [1,2]. Once dyes have served their function, they are often flushed into environmental water sources without further consideration. The presence of dye effluents in the environment is considered to be caused by five major industries, textile and dyeing represents about $75 \%$ for dye effluents [3]. Developing a permanent solution to remove dye particles from textile effluents will be highly beneficial to the environment [4,5]. Numerous studies are currently being conducted to determine the best dye removal process, so that dye wastewater can be recovered and reused [6]. Existing dye removal methods can be classified into biological, chemical, and physical processes [7]. The most economic and environmental effective method is the physical one as it didn't involve using of toxic chemicals and didn't leave toxic byproducts. Physical techniques used in the dye removal process can be divided into membrane based technique and adsorption. Adsorption process is considered one of the most favorable technique because of its remarkable ability to remove most types of dyestuff in addition to its simplicity and efficiency [8-12].

There are several different types of synthetic dyes, and they can be classified based on their molecular structure, solubility and applications [1,12]. Among synthetic dyes, azo dyes are the most common, providing for 60-70 percent of total dye consumption. Azo dyes are complex aromatic compounds with a wide range of structural characteristics, and they are a major environmental concern because the reductive cleavage of azo linkages results in the formation of amines, which are toxic and carcinogenic [13]. Congo red (CR) dye is a benzidine-based anionic diazo dye (1-naphthalenesulfonic acid, 3,3'-(4,4'-biphenylenebis(azo))-bis(4-amino) disodium salt), and it was reported known carcinogen and had affects the aquatic life [14,15]. Coagulation, focculation, chemical oxidation, photochemical degradation, and biological degradation are mostly techniques for removing dyes from an aqueous medium. All of the methods mentioned above, however, have some disadvantages, and none of them have been effective in 
completely removing dye from wastewater [16]. For its simplicity, ease of recovery, and reusability of the material, adsorption is the most effective treatment method for removing dye from aqueous solution. Numerous types of adsorbents have been employed for CR removal. Activated carbon is one of the most widely used adsorbent for dye removal [17-21]. Biopolymers as chitosane and nanochitosane were been used as a prominent adsorbent for CR removal [22-27]. Modified nanochitosane loaded on zeolite was used as an efficient adsorbent of CR dye [28]. Different nanomaterials and nanocomposites have also been reported as dye's adsorbnts [29-33]. Textile industry wastes containing acrylic fibres can cause environmental issues. As a result, several researchers have attempted to repurpose fibre waste in concrete and soil enforcement, as well as in the adsorption process after chemical treatment. Acrylic fibers mainly composed of at leat $85 \%$ acylonitil and the remaining is acother acrylic monomer used for improve the processing of the fiber as dyebility and wetability. There are limited paper dealing with the recycling of acrylic fibers in different form for water remedition application. Lehia and Akbari used acrylic fibers and fuzzes wasted in carpet industries to prepare adsoprtion membrane for removing Persian Orange $\mathrm{X}$ from textile effluents [34]. Poly acrylonitrile Nanofiber materials have been recenltly used as CR adsorbent and heavy metal removal [35-38]. Also modified acrylic fiber waste have been recently used for removal uranium and thorium from liquid waste soln [39].

This reasearch work was aimed to preapre a novel nancomposite flms based on commerisal acrylic fibers waste and nanochitosane and their study in adsorption of CR from aqeuous solution. Different parameters affecting the adsrotpion efficiency such as $\mathrm{CR}$ concentrations, adsorbent dose, effect of time and $\mathrm{pH}$. were investigated. Also kinetic study and ithotherm of adsorbtion process were studied.

\section{2- Experimental}

\section{2-1 Materials:}

Acrylic fiber waste (AF) consisting of at least $85 \%$ polyacrylonitrile as a major constituent and the residual mainly vinyl acetate or methyl acrylate copolymer was obtained from local textile industry. Congo red dye was supplied from Alpha Aeser, India, Commercial Chitosan of low molecular weight (150 kDa), Trisodium 
polyphosphate (TPP), Epichlorohydrin (EPH) and Dimethylformamide (DMF) were purchased from Sigma Aldrich, USA. Hydrochloric acid and Sodium hydroxide and other solvents were supplied from El-Nasr Company Egypt.

\section{2-2 Preparation of nanochitosan}

Nanochitosan was synthesized according to ionic gelation method using TPP as crosslinking agent [40]. Briefly, one gm of chitosan was dissolved in $200 \mathrm{ml}$ of $1 \%$ of acetic acid, then $0.2 \mathrm{~g}$ of TPP was dissolved in $50 \mathrm{ml}$ of distilled water and added drop wise to chitosan solution under constant stirring forming turbid solution indication the formation of nanoparticles. The suspension was left under stirring for another one an hour after complete addition step. The nanochitosan was separated using centrifuge at a maximum of $10.000 \mathrm{rpm}$, and collected then freeze dried.

\section{2-3 Preparation of acrylic fiber-nanochitosan composite films (AF-NCh)}

Composite films of AF with different ratios of $\mathrm{NCh}(0,10,20,30,40,50 \& 60$ wt. \%) were prepared as following, a predetermined weight of AF waste is dissolved in $10 \mathrm{ml}$ DMF at $70^{\circ} \mathrm{C}$ under stirring for $4 \mathrm{~h}$., then a definite weight of $\mathrm{NCh}$ was added portion wise to the PAN-DMF solution with continuing stirring till obtain a homogenous composite solution. The obtained homogenous suspension was sonicated for one hour in ultrasonic water bath to confirm the well distribution of nanochitosan in the polymer matrix. The composite solution was casted in a glass plate using a film applicator. The casting solution was immersed in deionized water for $24 \mathrm{~h}$ to get a film with thickness of $0.12 \mathrm{~mm}$. By adopting the same procedures, other composite film was prepared using a cross linking EPH to assure complete fixation of nanochitosan within the polymer matrix.

\section{2-4 Characterization}

\subsubsection{FTIR studies}

To assess the reactive function groups of the composite films FT-IR was used within the range (400- $4000 \mathrm{~cm}^{-1}$ ) using Nicolet Avatar FTIR 370 CSI. 


\subsubsection{SEM of composite film}

Surface morphology and the cross-section topography of the synthesized composite films were investigated using FESEM QUANTA 250. Prior to examination the films were dried and sputtered with gold to minimize charging effect during examination.

\subsubsection{TEM of nanochitosan:}

The particle size and shape of synthesized nanochitosan was investigated using HRTEM, (JEM-2100 -TEM). The nanochitosan suspension was sonicated for half an hour and one or two drops were added to the testing grid then left for dyeing.

\subsubsection{Brunauer-Emmett-Teller (BET) measurement}

The Brunauer-Emmett-Teller (BET) measurement was used to assess the surface area of the composite films based on determination of nitrogen adsorption isotherm at $77 \mathrm{~K}$ using the Belsorp adsorption automatic specific surface area analyzer (Microtrac-BEL , Japan).

\subsection{Thermal gravimetric analysis (TGA).}

Thermal stability of the new nanocomposite was investigated using TA Q500 instrument, at a heating rate $10{ }^{\circ} \mathrm{C} / \mathrm{min}$ in nitrogen atmosphere.

\subsection{Adsorption and Optimization Experiments}

Different concentrations of CR dye ranged from 100-800 mg/l have been prepared. The final concentration after adsorption and the feed solution were measured using UV-vis (Lambda 35 Perkin Elmer) at $\lambda \max =497 \mathrm{~nm}$. A predetermined weight of AF-NCh and $\mathrm{AF}-\mathrm{NCh}-\mathrm{EPH}$ films were inserted into $50 \mathrm{ml}$ glass round flask, then $10 \mathrm{ml}$ of CR dye solution of variant concentrations were added. The flask was shaken using automatic shaker at $50 \mathrm{rpm}$ for $24 \mathrm{~h}$. Various parameters of adsorption study were employed such as time of shaking, CR dye concentration, adsorbent dose and solution $\mathrm{pH}$.

The adsorption capacity $\mathrm{q}\left(\mathrm{mg} \cdot \mathrm{g}^{-1}\right)$ for $\mathrm{CR}$ dye can be calculated using the mass balance expression, equation (1)[41].

$$
q_{e}=\left(C_{0}-C_{e}\right) \times V / m
$$


Where $\mathrm{C}_{0}$ and $\mathrm{C}_{\mathrm{e}}$ are the initial and equilibrium concertation of the dye, respectively, expressed in $(\mathrm{mg} / \mathrm{L}), \mathrm{V}$ is the volume of the dye solution in $(\mathrm{L})$ and $\mathrm{m}$ is the mass of the adsorbent in $(\mathrm{g})$.

The removal efficiency at equilibrium can be calculated using the following relation, equation (2) [42].

$$
\% R=\frac{\left(C_{0}-C_{e}\right)}{C_{0}} \times 100
$$

\subsection{Adsorption isotherm studies}

Langmuir and Freundlich isotherm models were applied to assess the affinity between the adsorbent and adsorbate. The mathematical equations expressed the adsorption models are illustrated below by equations $(3,5)[43]$.

$$
\frac{C_{e}}{q_{e}}=\frac{1}{q_{\max } k_{l}}+\frac{C_{e}}{q_{\max }}
$$

Where $k_{l}$ represents a constant related to the nanocomposites adsorption/desorption capacity, and $\mathrm{q}_{\max }$ is the maximum adsorption capacity upon complete saturation of the nanocomposites, $\mathrm{Ce}(\mathrm{mg} / \mathrm{L})$ is the dye concentration at equilibrium and $\mathrm{q}_{\mathrm{e}}(\mathrm{mg} / \mathrm{g})$ is the adsorption capacity at equilibrium.

The basic parameter of the Langmuir isotherm could be expressed in terms of a unitles $\mathrm{s}$ equilibrium factor, such as the separation factor or equilibrium factor $\left(R_{\mathrm{L}}\right)$ (Eq.4).

$$
\mathrm{R}_{\mathrm{L}}=1 / 1+\mathrm{K}_{1} \mathrm{C}_{0}
$$

Where, $\mathrm{C}_{\mathrm{o}}$ is the initial dye's concentration.

The Freundlich isotherm is presented using equation [5].

$$
\log q_{e}=\log K+\frac{1}{n} \log C_{e}
$$

Where $\mathrm{k}$ and $n$ are empirical constants that can be related to the adsorption capacity and the adsorption affinity, respectively.

\subsection{Kinetic studies}

Pseudo first order and pseudo second order are most the common kinetic models used for detect the rate of dye adsorption from the aqueous solution. The linear forms of these models can be expressed in the following equations see (6-7) [44]. 
$\log \left(q_{e}-q_{t}\right)=\log q_{e}-k_{1} * \frac{t}{2.303}$

Where $\mathrm{q}_{\mathrm{e}}(\mathrm{mg} / \mathrm{g})$, is the adsorption capacity at equilibrium, $\mathrm{q}_{\mathrm{t}}(\mathrm{mg} / \mathrm{g})$ is the adsorption capacity at time $\mathrm{t}$, and $\mathrm{k}_{1}$ is the first order rate constant per minute.

A plot of $\ln \left(\mathrm{q}_{\mathrm{e}}-\mathrm{q}_{\mathrm{t}}\right)$ versus time ( $\left.\mathrm{t}\right)$ indicates a straight line of slope $\left(-\mathrm{k}_{1} / 2.303\right)$ and an intercept of $\log \left(\mathrm{q}_{\mathrm{e}}\right)$

Whereas the second order equation can be represented by equation (7)

$$
\frac{t}{q_{t}}=\frac{1}{k_{2} q_{e}^{2}}+\frac{1}{q_{e}} * t
$$

Where $\mathrm{K}_{2}$ expresses the equilibrium rate constant $\left(\mathrm{g} / \mathrm{mg} \mathrm{min}\right.$ ), and $\mathrm{q}_{\mathrm{e}}$ and $\mathrm{q}_{\mathrm{t}}$ express the sorption capacities at equilibrium and at time $(\mathrm{t})$, respectively. A plot $\mathrm{t} / \mathrm{q}_{\mathrm{t}}$ versus $\mathrm{t}$ shows a straight line of slope $\left(1 / \mathrm{q}_{\mathrm{e}}\right)$ and an intercept of $\left(1 / \mathrm{K}_{2} \mathrm{q}_{\mathrm{e}}^{2}\right)$.

\section{Result and discussion:}

\subsection{Characterization of the synthesized nanochitosan.}

Figure 1a. displayed FTIR of chitosan and nanochitosan, it showed a distinct shift of $\mathrm{OH}$ and $\mathrm{NH}$ to alower wave number from $3437 \mathrm{~cm}^{-1}$ for chitosan to $3415 \mathrm{~cm}^{-1}$ for nanochitosan with large brodining indicating the pyscial ineraction with TPP. Peaks of $\mathrm{C}=\mathrm{O}$ of amide (chitin part) at $1640 \mathrm{~cm}^{-1}$ and $\mathrm{C}-\mathrm{O}$ at $1150 \mathrm{~cm}^{-1}$ were obtained [45]. For nanochitosan adistnict peaks were appeared at 1080 and $1210 \mathrm{~cm}^{-1}$ for $\mathrm{P}-\mathrm{O}$ and $\mathrm{P}=\mathrm{O}$ streating, respectively.

Figure $1 \mathrm{~b}$ showed HRTEM images of the nanochitosan particle. The NCh had a relatively spherical shape and a narrow particle size distribution, with sizes ranging from 60 to $80 \mathrm{~nm}$. The NCh exists showed some aggregates due to the highly interactive attraction force between particles [46]. Figure 1c indicated the particle size of chitosan measured using zeta Sizer (Malvern instrument Version 7.04). The figure indicated that the average particle size of the nanoparticle was $98 \mathrm{~nm}$ with narrow distribution. The relatively higher particles size of chitosan in DLS rather in TEM is that the measurement in DLS was performed in aqueous media and the chitosan nanoparticles were in swollen state that give relatively larger size. However in TEM measurement the particles were in dried state and selected image were obtain to confirm the particle size. 

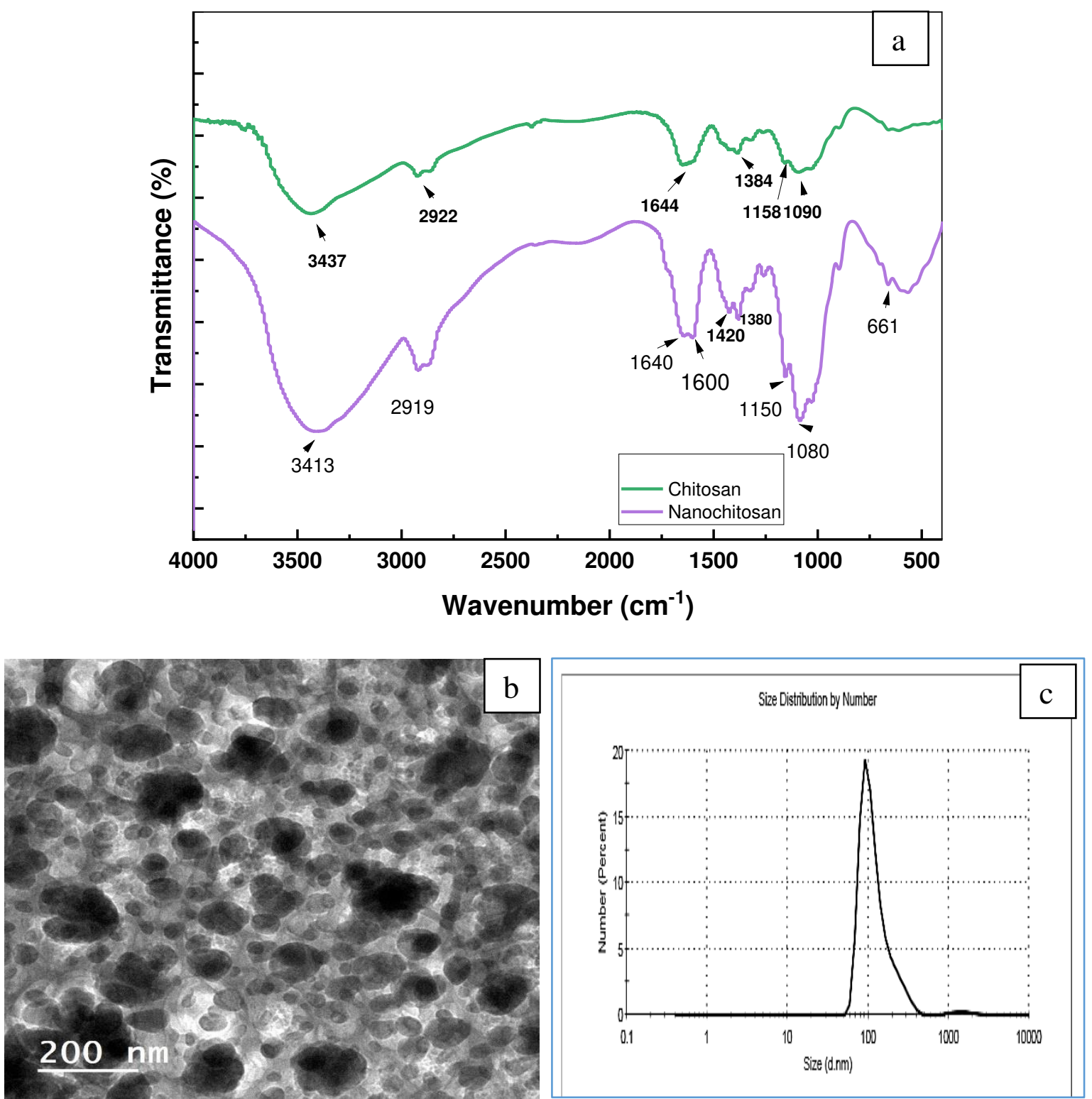

Figure 1. a) FTIR spectra of chitosan and nanochitosan, b) TEM of nanochitosan and c) DLS measurement of the nanochitosan

\subsection{Characterization of the composite films}

\subsubsection{FTIR spectra}

FT-IR spectra of the prepared AF film, and nanocomposites films have been investigated as shown in figures 2 . 


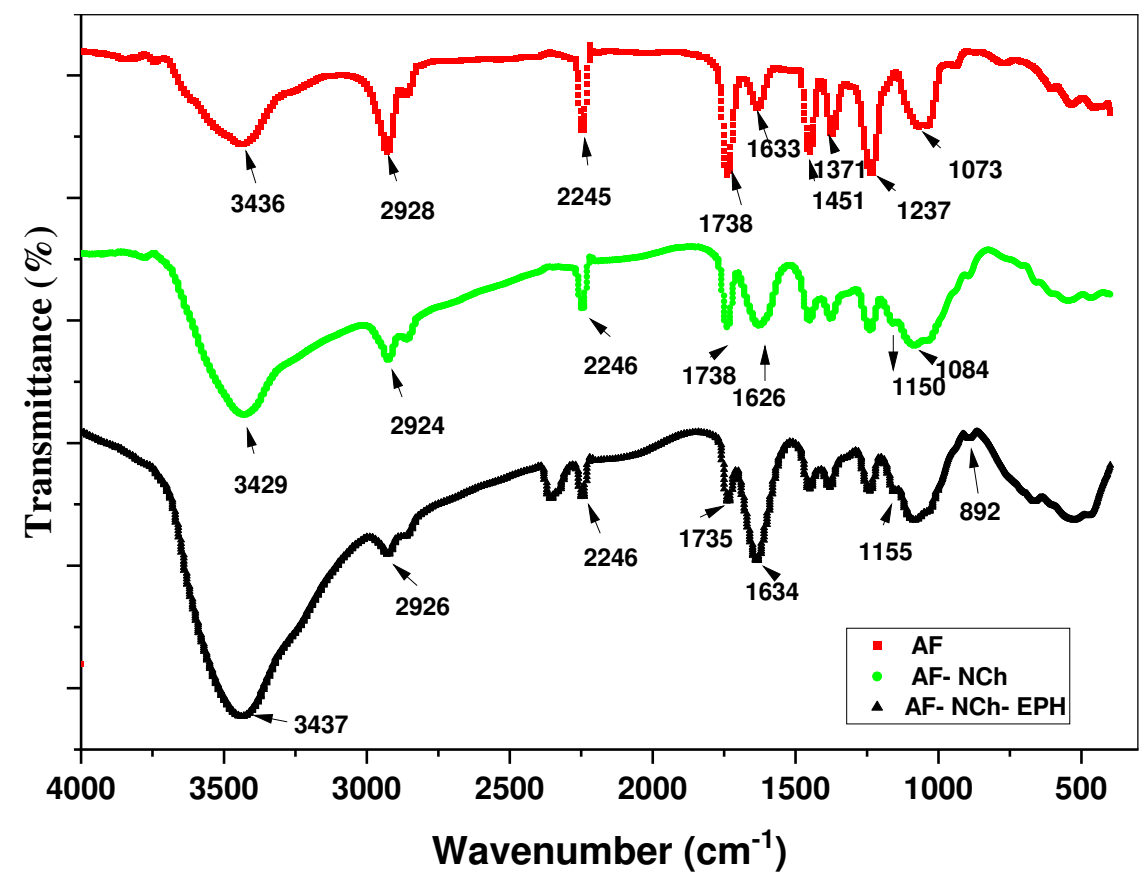

Figure 2. FTIR of collected spectra of AF, AF-NCh and AF-NCh-EPH

As shown in the figure 2, AF film have many peaks; the absorption peaks at $2928 \mathrm{~cm}^{-}$ ${ }^{1}$ and 2885 were related to stretching $\mathrm{C}-\mathrm{H}$ bonds in $\mathrm{CH}_{3}$ and $\mathrm{CH}_{2}$. Another peak is at $2245 \mathrm{~cm}^{-1}$ which is assigned to presence of nitrile $(\mathrm{C} \equiv \mathrm{N})$ groups. Peak at $3436 \mathrm{~cm}^{-1}$ is may be related to $-\mathrm{OH}$ of adsorbed water by additives present in commercial AF [39]. The peaks at $1638 \mathrm{~cm}^{-1}$ and $1738 \mathrm{~cm}^{-1}$ results from presence of $\mathrm{C}=\mathrm{O}$ related to comonomers like butyl acrylate and methyl acrylate and peaks at 1073 and $1237 \mathrm{~cm}^{-1}$ may be related to and C-O stretching, the peaks at $1371 \mathrm{~cm}^{-1}$ is related to bending motions of C-H bond [47].

FTIR of copmosites films AF-NCh and AF-NCh-EPH declares that the intensity of $\mathrm{C} \equiv \mathrm{N}$ and $\mathrm{C}=\mathrm{O}$ ester is decreased comparing to pure $\mathrm{AF}$ and observed at $2246 \mathrm{~cm}^{-1}, 1738$ $\mathrm{cm}^{-1}$ and $1735 \mathrm{~cm}^{-1}$ respectively. $\mathrm{NH}$ and $-\mathrm{OH}$ peaks are observed at $3429 \mathrm{~cm}^{-1}$ and $3437 \mathrm{~cm}^{-1}$ espectively.

\subsubsection{SEM of AF and nanocomposites films}

Figure 3-a showed the topography of plain surface of AF film, which revealed the highly porous structure. Figure 4-a displayed the cross section of AF which declared the pores and macro voids structure resulted from spontaneous demixing of solvent (DMF) non solvent (water) during phase inversion process. Figure 3-b and 4-b showed the plain 
and cross section of composite AF-NCh, which declared the enhanced macrovoids structure. The figures also showed the inclusion of spherical shape nanoparticles indicating nano-chitosan incorporation into AF matrix, which lead to increasing active sites for dye adsorption process. For the other prepared AF-NCh-EPH nanocomposites figures 3-c and 4-c displayed the plain and cross-section surface, which revealed a significant fixation of $\mathrm{NCh}$ into $\mathrm{AF}$ matrix which leads to an enhancement in adsorption efficiency with good stability.
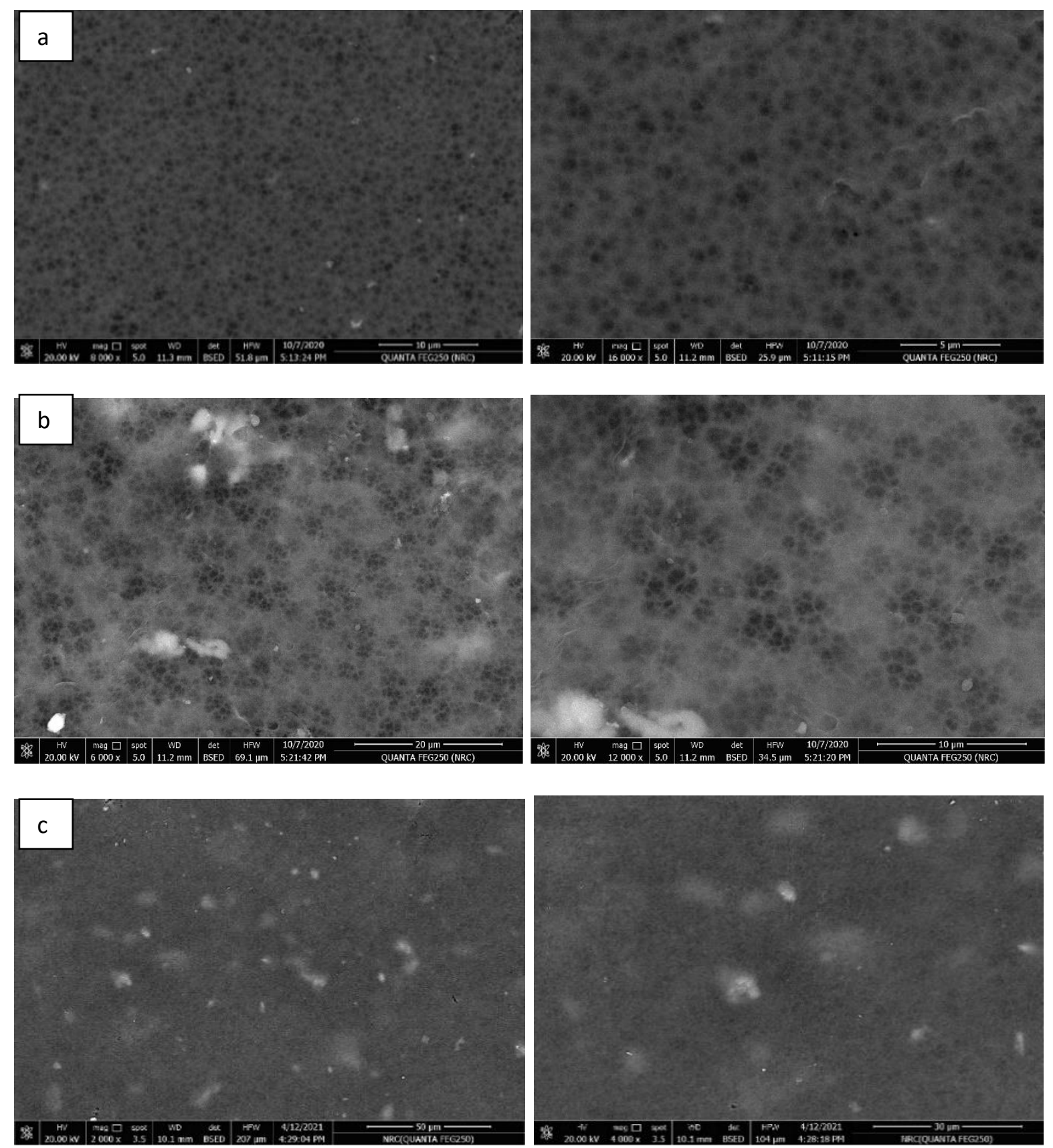

Figure (3) SEM of film surface for a) AF b) AF-NCh and c) AF-NCh-EPH 

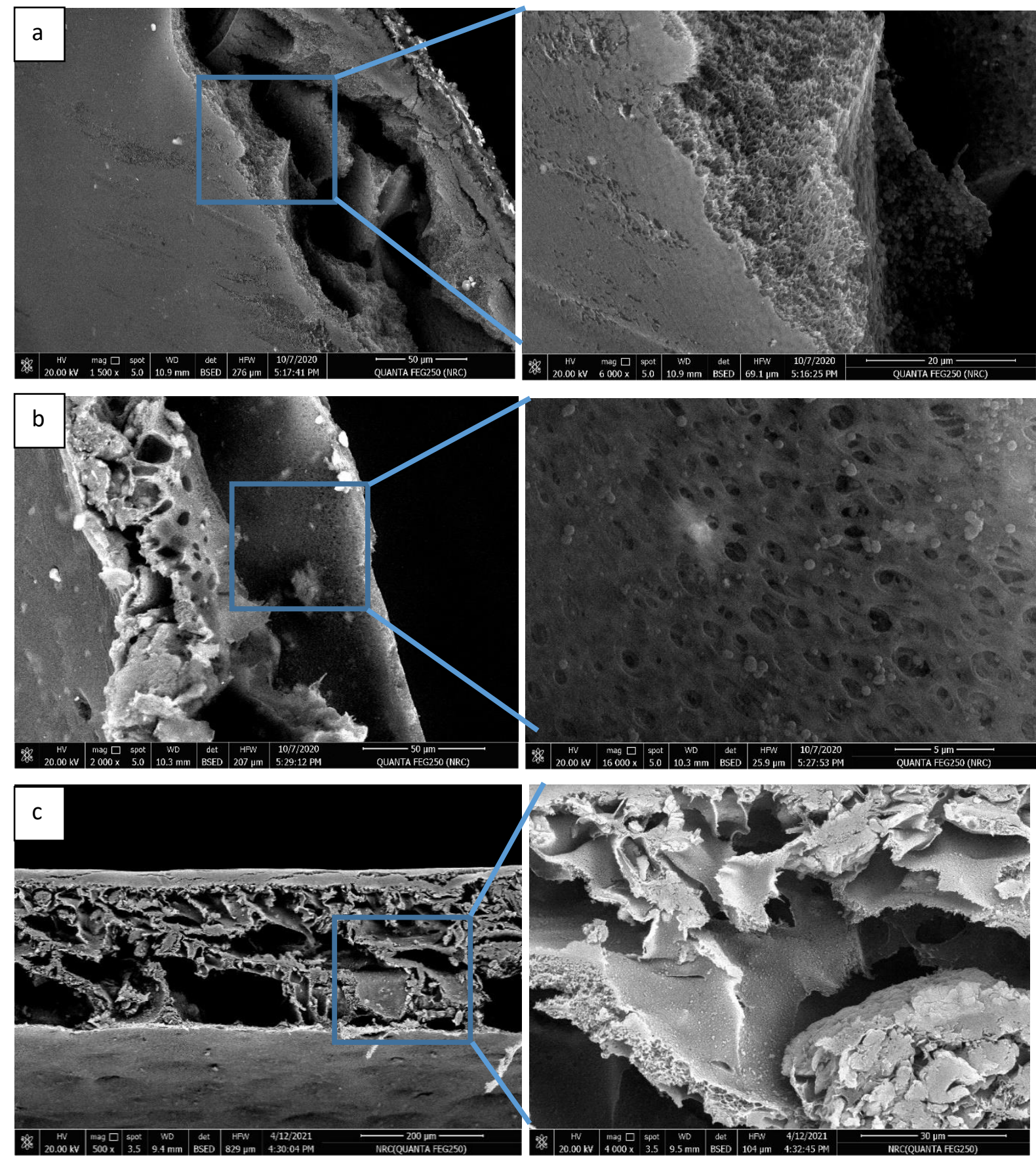

Figure (4) SEM of film cross-section for a) AF b) AF-NCh c) AF-NCh-EPH

\subsubsection{Brunauer-Emmett-Teller (BET) measurement}

BET analysis of the synthesized films is summarized in table (1). From BET data we can noticed that surface area of AF film decreased upon addition of NCh and NCh-EPH. This may be due to the inclusion of high content of nano-chitosan with high entangled force of these particles. But in spite of decrease the surface area of nanocomposite film but they have high adsorption capacity to CR dye compared to AF film because of they have hydrophilic function group as $\left(-\mathrm{OH}\right.$ and $\left.-\mathrm{NH}_{2}\right)[48]$. 
Table 1 BET surface area and the pore structure of the synthesized adsorbents

\begin{tabular}{|c|c|c|c|}
\hline Sample & S & Pere volume $\left(\mathbf{V}_{\mathbf{m}}\right)$ & $\begin{array}{c}\text { Average pore } \\
\text { size }(\mathbf{n m})\end{array}$ \\
\hline AF & 48 & 11.2 & 17.4 \\
\hline AF-NCh & 9.3 & 2.1 & 9 \\
\hline AF-NCh-EPH & 19 & 4.3 & 14.4 \\
\hline
\end{tabular}

\subsubsection{Thermal gravimetric analysis}

The thermal stability of modified and unmodified AF-NCh was studied using thermal gravimetric analysis. Figure 5 illustrated TG and DTG curves of AF films; AF, AFNCh and AF-NCh-EPH composites. For blank AF film there was a distinct one phase due to degradation process of the main chains. The onset degradation temperature was at $349^{\circ} \mathrm{C}$. For the prepared nanocomposites AF-NCh and AF-NCh-EPH, it was obvious a distinct two phases of degradation process, which confirmed the successful physical mixing of nanochitosan into AF film matrix. For AF-NCh the first onset degradation process was at $289{ }^{\circ} \mathrm{C}$, attributed to nanochitosan degradation. The second onset degradation temperature was at $353^{\circ} \mathrm{C}$, for AF degradation. For AF-NCh-EPH the first onset degradation process was at $276^{\circ} \mathrm{C}$, attributed to nanochitosan degradation. The second onset degradation temperature was at $343{ }^{\circ} \mathrm{C}$ for $\mathrm{AF}$ chains. It was noticed that the using of crosslinking EPH decrease the thermal stability of the nanocomposites, which may be due to the decrease in oriented packing chain of AF resulted from nanochitosan [49]. 

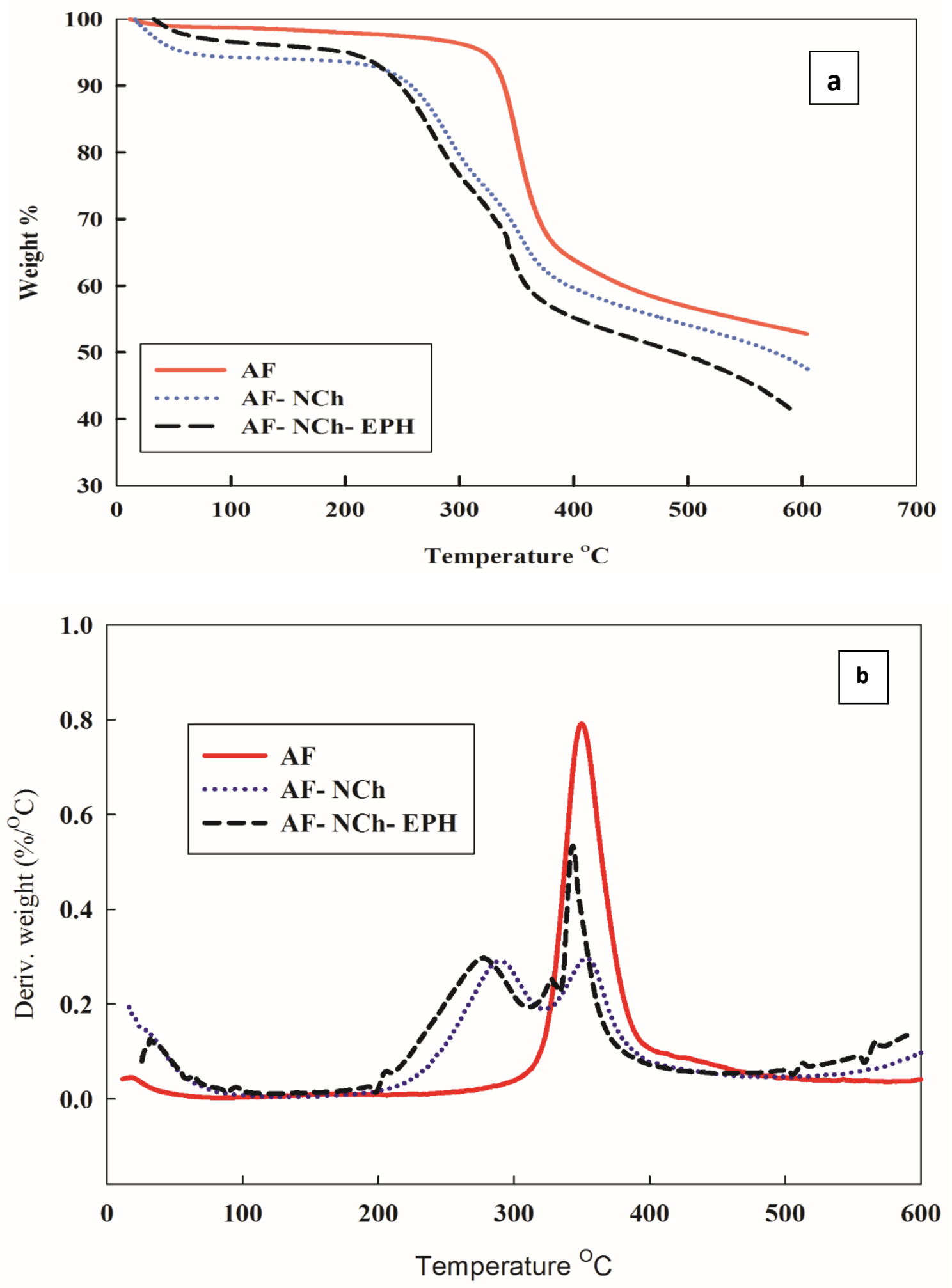

Figure 5 (a) TG and (b) DTG curves of AF, AF-NCh and AF-NCh-EPH 


\subsection{Adsorption study}

\subsubsection{Effect of loading percent of NCh on adsorption behavior for Congo red dye.}

The effect of loading percent of nano-chitosan into AF films was studied to measure the efficiency for CR dye removal. Weight of $0.025 \mathrm{~g}$ of AF-NCh with different nanochitosan ratio $(0,10,20,30,40,50,60 \mathrm{wt} \%)$ was inserted into a $10 \mathrm{ml}$ of $200 \mathrm{mg} / \mathrm{l} \mathrm{CR}$ dye. The adsorption process occurred using a mechanical shaker at $50 \mathrm{rpm}$ for $24 \mathrm{~h}$. Figure 6 showed the relation between percent loaded nanochitosan and $\%$ removal (\%R) of CR dye. It was clear from the figure the increment of efficiency of CR dye upon increase of nanochitosan loaded percent onto AF film till $50 \mathrm{wt} \%$ after that it reached a plateau with no observed enhancement. The higher efficiency was due to high aspect ratio of reactive functional group (amine and hydroxyl groups) present in nanochitosan. Also the high surface area of nanoparticles may enhance the adsorption capacity [5052]. One can see from the figure that the optimum removal efficiency ( $\mathrm{R} \%)$ was about 98\% of CR for nanochitosan with 50\% loading into AF film, afterword have no significant change of $\% \mathrm{R}$. This can be attributed the aggregation and accumulation of the nanoparticle during the composite preparation that decrease the active surface area for the adsorption [53]. 


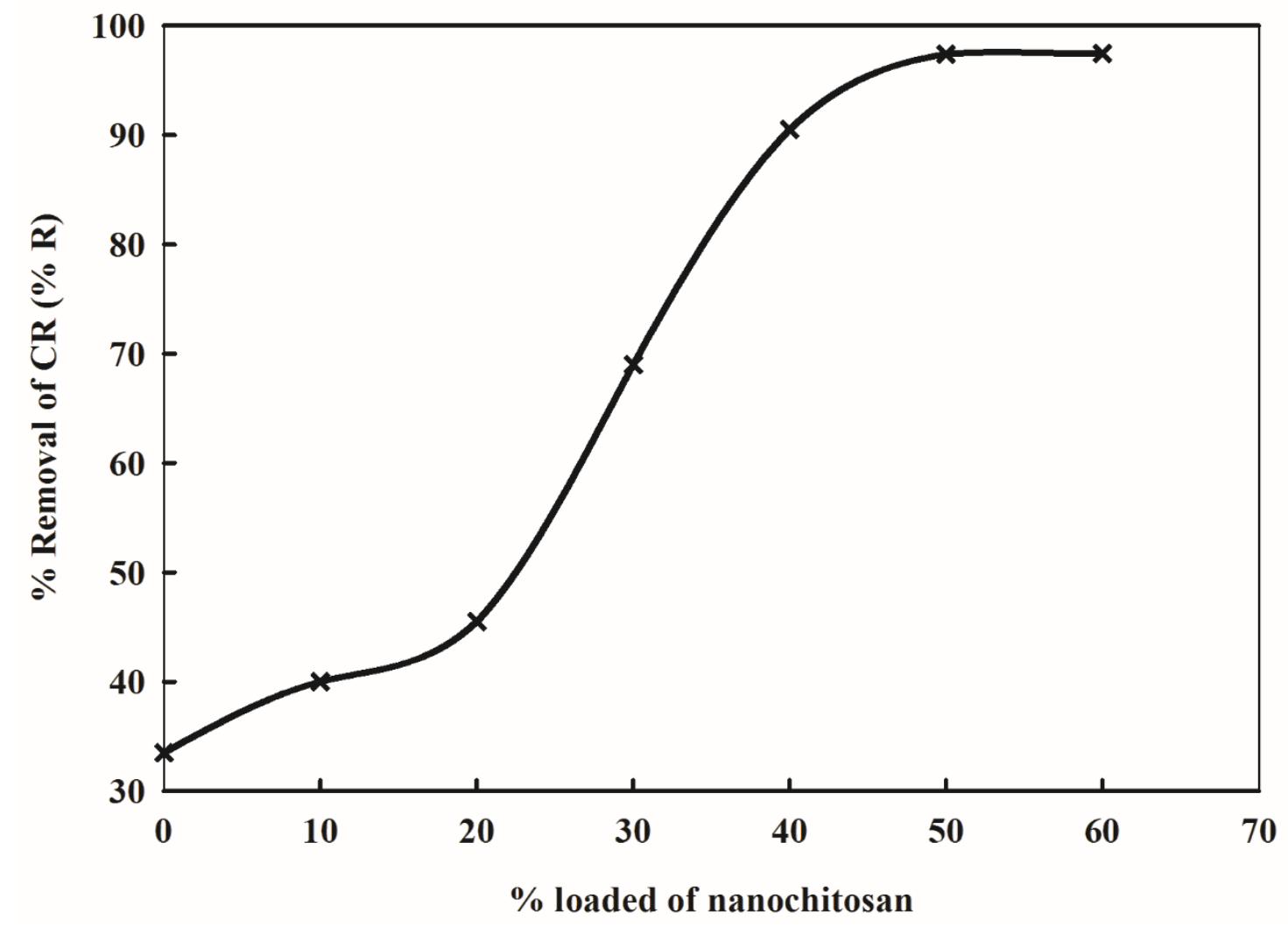

Figure 6 effect of nanochitosan percent loaded onto AF on \% removal of CR

\subsubsection{Effect of dye concentration}

Figure $7(\mathrm{a} \& \mathrm{~b})$ declared the effect of CR concertation on adsorption capacity within a day $(24 \mathrm{~h})$ at $\mathrm{pH}=5.5,0.025 \mathrm{gm}$ adsorbent weight of AF-NCh and AF-NCh -EPH at temperature $25{ }^{\circ} \mathrm{C}$ with a series of $\mathrm{CR}$ dye ranged from 100 to $800 \mathrm{mg} / \mathrm{l}$ was adopted for the study. From figure 7 ( $\mathrm{a} \& \mathrm{~b}$ ) the best adsorption R\% was achieved at a CR dye concentration of $400 \mathrm{mg} / \mathrm{l}$ with values $92.5 \%$ and $96.8 \%$ for AF-NCh and AF-NCh EPH respectively. Also we can noticed that the higher concentration above $400 \mathrm{mg} / \mathrm{l}$ showed less percent removal efficiency because of most active cites of a predetermined adsorbent weight dose was occupied at CR dye concentration of $400 \mathrm{mg} / \mathrm{l}$. 

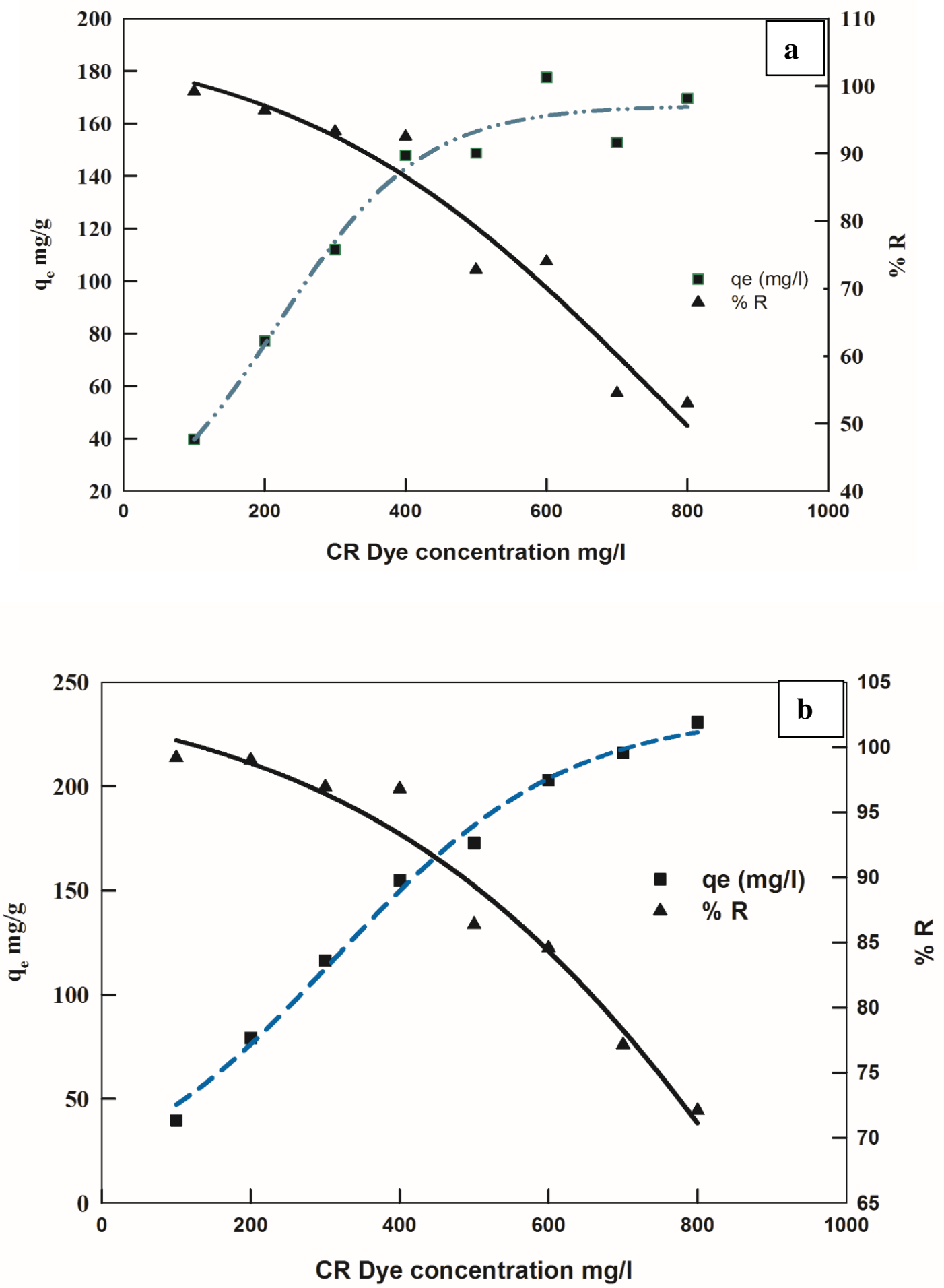

Figure 7. Effect of CR dye concentration on adsorption capacity and \% dye removal of (A) AF-NCh and (B) AF-NCh-EPH 


\subsubsection{Effect of $\mathrm{pH}$}

Table 2 summarize adsorption capacity for $\mathrm{CR}$ dye removal at two different $\mathrm{pH}$. It can be seen from the table that the highest adsorption capacity was achieved at $\mathrm{pH} 5.5$, this due to; at relatively acidic condition $\mathrm{pH} 5.5$ the amino group of nanochitosan get protonated (cationic structure), which increase the interaction to the anionic dye (CR). At $\mathrm{pH} 8$ adsorption capacity appears to significantly decrease for the CR dye. This due to , at slightly basic solution the negative charge of $\mathrm{OH}^{-}$groups made a repulsive force of CR dye anionic structure, thus desorption process predominates [22].

Table 2 effect of $\mathrm{pH}$ variation on adsorption capacity of synthesized films

Dye Conc. mg/l pH q mg/g (AF-NCh) q mg/g (AF-NCh-EPH)

$\begin{array}{lll}5.5 & 148 & 154.8\end{array}$

400

$\begin{array}{lll}8 & 114.4 & 138.8\end{array}$

\subsubsection{Effect of contact time}

Figure 8-a indicated the effect of contact time on the adsorption capacity of composite films for CR dye. As it can be seen from the figure that the increase the time the increased adsorption capacity for both films (AF/NCh and AF/NCH-EPH). The increased capacity was due to the available reactive functional that consumed over the progress of time. The figure showed slow adsorption pattern; as it need much time for attain equilibrium, and this result may be due to the relative hydrophobic nature of the polymer matric that render the movement of the dye molecules into the bulk of polymer matrix.

\subsubsection{Effect of adsorbent dose}

In our study, different adsorbent dose, 1.25, 2.5, 5 and $7.5 \mathrm{~g} / \mathrm{l}$ of AF-NCh \& AF-NChEPH films were used for removal of $400 \mathrm{ppm}$ CR dye soln. for $240 \mathrm{~min}$. The \%R and $\mathrm{q}_{\mathrm{t}}$ was plotted in figure $8 \mathrm{~b}$. From the figure the dye percent removal was enhanced and increased upon increase the adsorbent dose. This was attributed to increase of surface area and active sites of adsorbent as previously reported. 

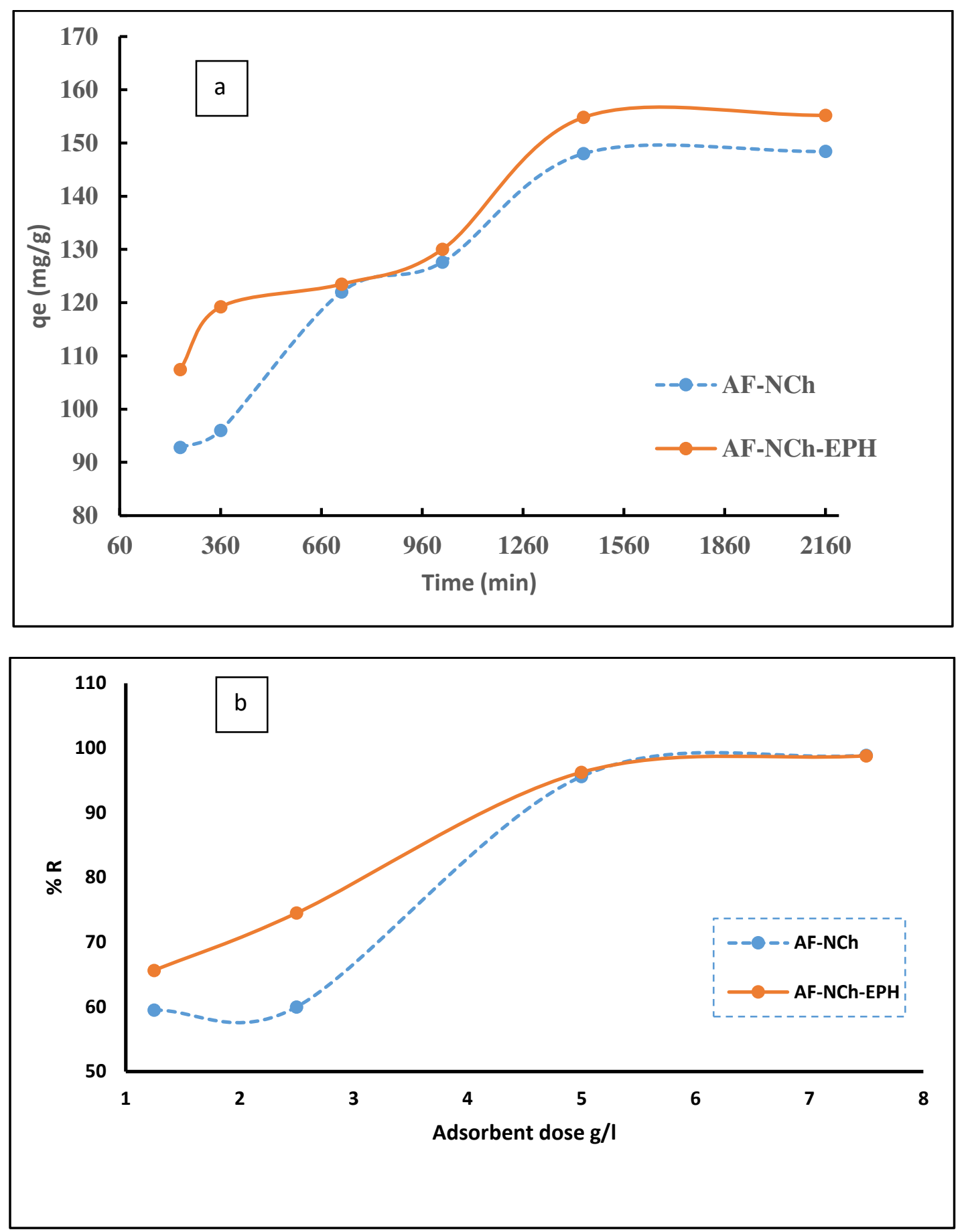

Figure 8. Effect of (a) adsorbent time and (b) adsorption dose on CR dye \%R

\subsection{Adsorption isotherm study}

The two linear adsorption isotherms, Langmuir and Freundlich, were used to evaluate the adsorption adsorbate affinity interaction. The Langmuir model was illustrated by a linear plot between a specific sorption $(\mathrm{Ce} / \mathrm{Qe})$ and the equilibrium concentration $(\mathrm{Ce})$. We get $1 / q_{\max }=$ slope and $1 / q_{\max } k_{l}=$ intercept. For Freundlich isotherm by plotting 
linearized curve between $\log q_{e} \mathrm{mg} / \mathrm{g}$ and $\log C_{e} \mathrm{mg} / \mathrm{l}$. We get $\log \mathrm{K}=$ intercept and $1 / n=$ slope. The Linear Langmuir and Freundlich isotherms plot and their calculated parameters were showed in Figure 9 and table 3. From figure and calculated data, the adsorption nature of CR by AF-NCh \& AF-NCh-EPH were more fitted to Langmuir isotherm. This can be attributed to the high $\mathrm{R}^{2}$ value compared to Freundlich isotherm (table 3 ) and the relatively close value of qmax to the experimental one. Moreover, these results according to Langmuir were due to the adsorbent surface homogenous nature. Thus CR dye adsorbed completely to the synthesized films active sites via monolayer formation mechanism [54,55]. Also $\mathrm{R}_{1}$ values ranged from 0.052 to $0.0068 \& 0.086$ to 0.011 for AF-NCh \& AF-NCh-EPH respectively, which indicates favored CR dye to the nanocomposites adsorbent materials [56].

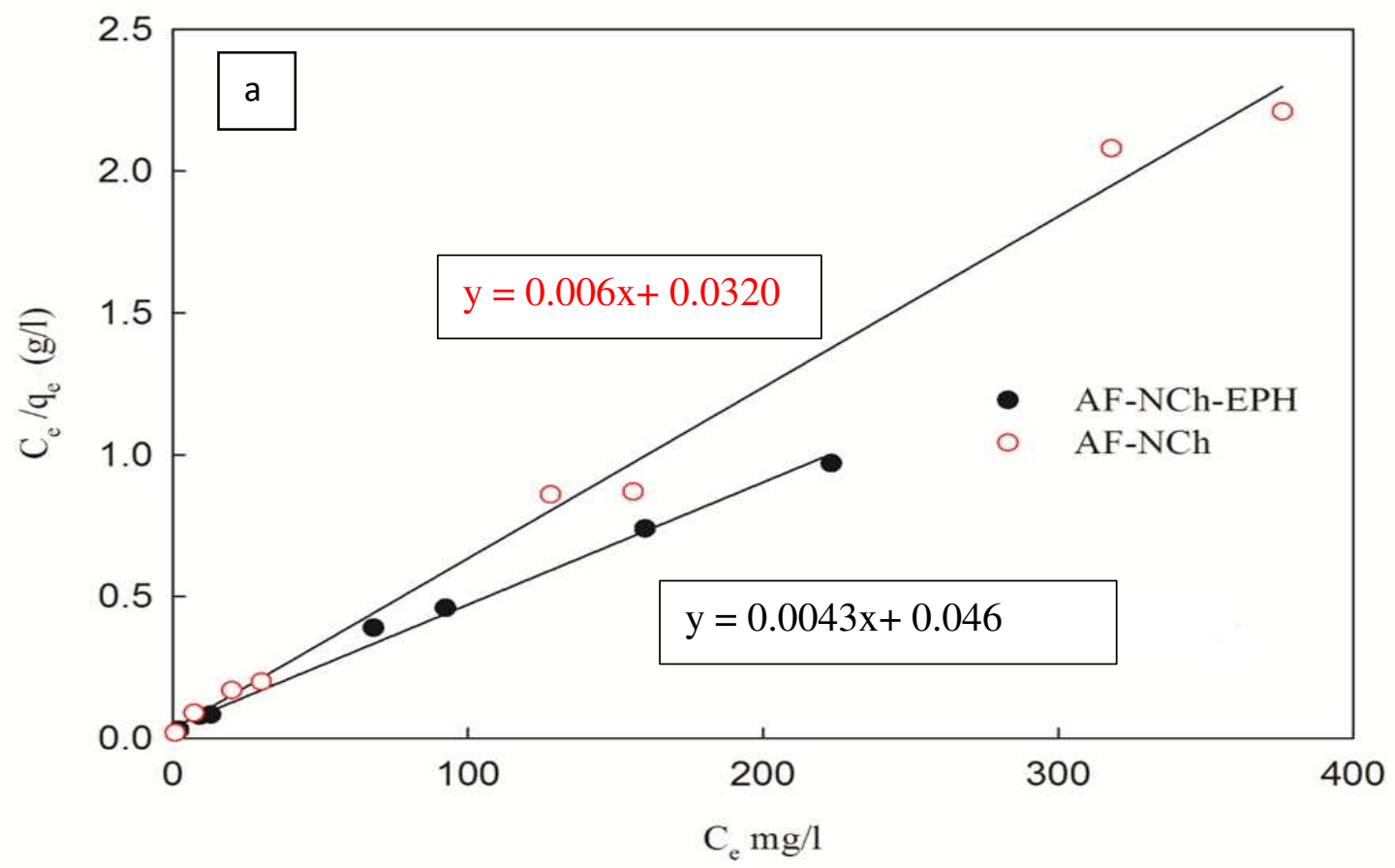




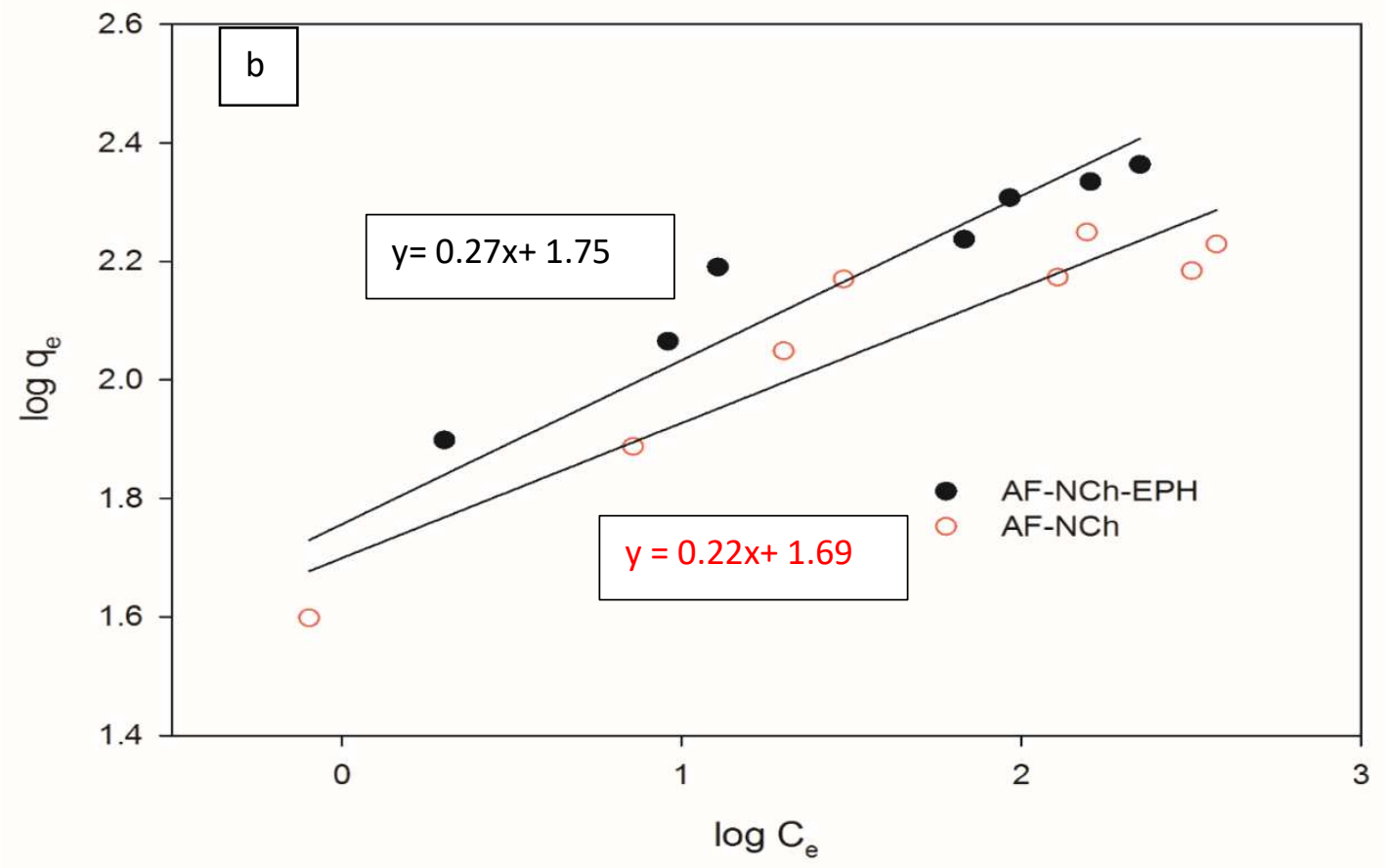

Figure 9. Langmuir (a) and Freundlich (b) isotherms for CR dye adsorption by AFNCh \& AF-NCh-EPH.

Table 3 Langmuir \& Freundlich isotherms parameters for CR dye adsorption by AFNCh \& AF-NCh-EPH adsorbents

\begin{tabular}{lccc}
\hline & Parameter & AF-NCh & AF-NCh-EPH \\
\hline & $\mathrm{R}^{2}$ & 0.992 & 0.997 \\
Langmuir & $\mathrm{Kl}$ & 0.18 & 0.106 \\
& $\mathrm{q} \max$ & 166.6 & 232.5 \\
\hline \multirow{2}{*}{ Freundlich } & $\mathrm{R}^{2}$ & 88 & 91 \\
& $\mathrm{~K}_{\mathrm{f}}$ & 48.9 & 56.2 \\
& $\mathrm{n}$ & 4.5 & 63.7 \\
\hline
\end{tabular}




\subsection{Kinetic study}

Pseudo first and second order models were adopted for our adsorption study of CR dye on AF-NCh \& AF-NCh-EPH composite films. A linearized curves were plotted for the two models (figures 10). The calculated parameters were summarized in table 4. From these data, we can conclude that pseudo second order mechanism is most fitted for adsorption of $\mathrm{CR}$ dye on the two synthesized films. The value of $\mathrm{R}^{2}$ of pseudo second order is higher than of pseudo first order as shown in table 4 . Also the calculated values qe were $125 \& 128.2$ for AF-NCh and AF-NCh-EPH, respectively, which are nearly fitted to the experimental values.

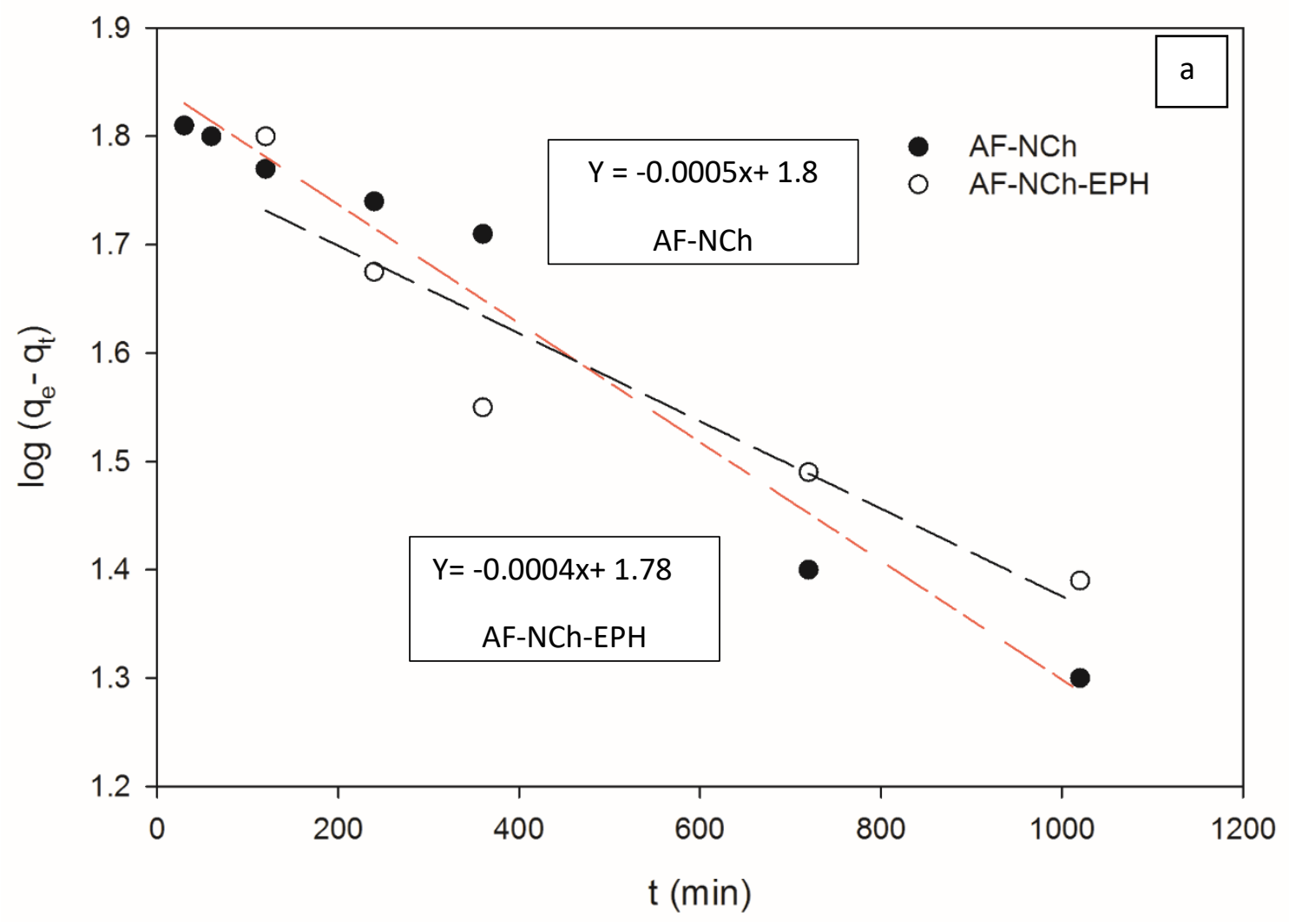




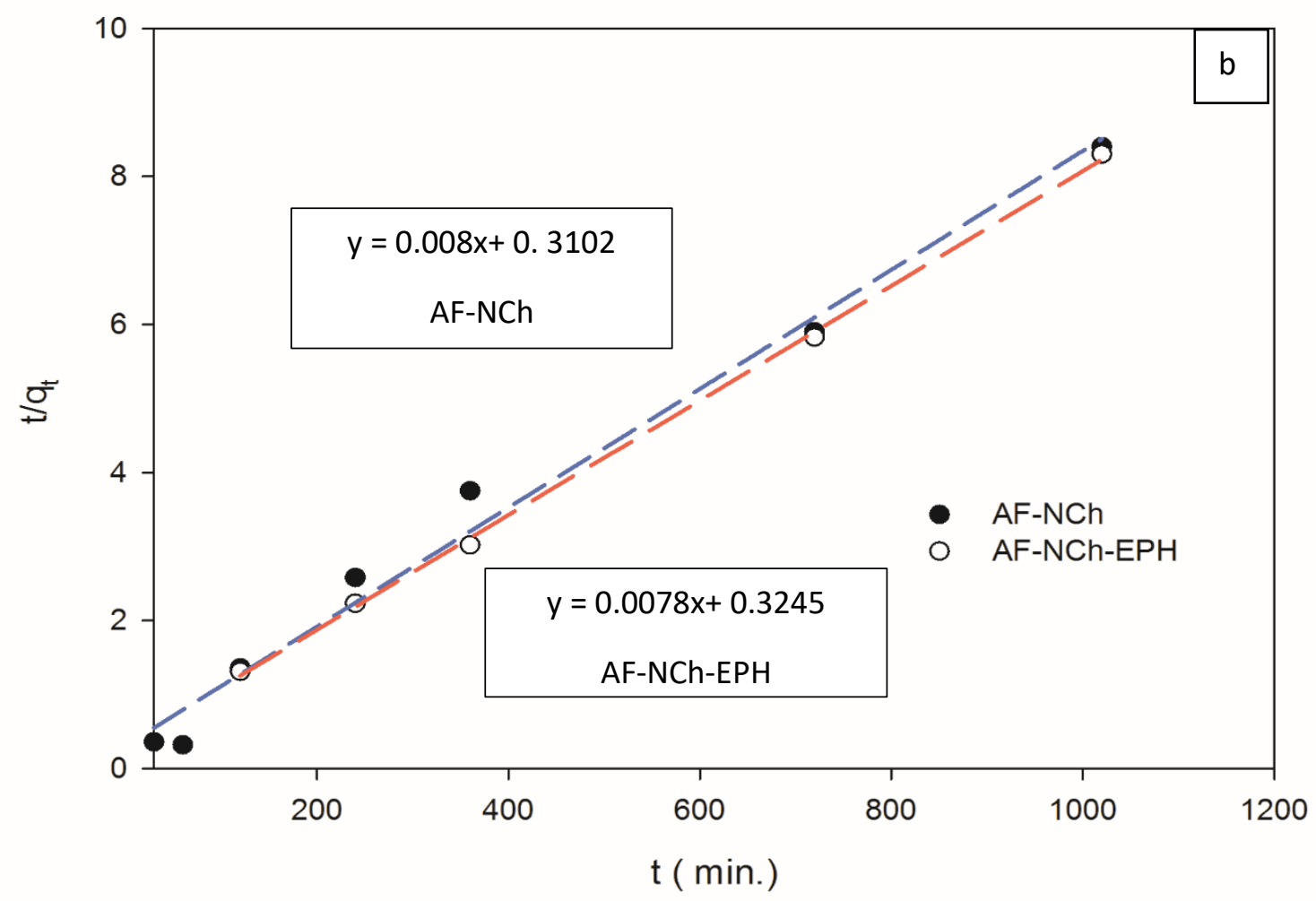

Figure 10 Pseudo first order (a) and second order (b) for CR dye adsorption by AFNCh \& AF-NCh-EPH.

Table 4 Pseudo first order \& Pseudo second order parameters for CR dye adsorption by AF-NCh \& AF-NCh-EPH.

\begin{tabular}{lccc}
\hline & Parameter & AF-NCh & AF-NCh-EPH \\
\hline & $\mathrm{R}^{2}$ & 0.97 & 0.88 \\
$1^{\text {st }}$ oder & $\mathrm{K} 1$ & $1.15^{*} 10^{-3}$ & $9.2 * 10^{-4}$ \\
& $\mathrm{qe}$ & 70.8 & 60.25 \\
\hline & $\mathrm{R}^{2}$ & 98 & 99 \\
$2^{\text {nd }}$ order & $\mathrm{K} 2$ & $2.06 * 10^{-4}$ & $1.87 * 10^{-4}$ \\
& $\mathrm{qe}$ & 125 & 128.2 \\
\hline
\end{tabular}




\subsection{Effect of film regeneration}

Regeneration of an adsorbent is an important step for economic view and practical use of this adsorbent in industries. The prepared nanocomposite films (AF-NCh and AFNCh-EPH) were regenerated using (50:50) ethanol: distilled water. Five cycles experiment were employed using $400 \mathrm{mg} / \mathrm{l} \mathrm{CR}$ dye solution. The result was shown in figure11. From the illustrated data we can state that; after five cycles of using the synthesized film the adsorption capacity slightly decrease by approximately $30 \%$ of their initial values. Thus the synthesized AF-NCh and AF-NCh-EPH films can be used several times as an adsorbent for CR dye with relatively good stability.

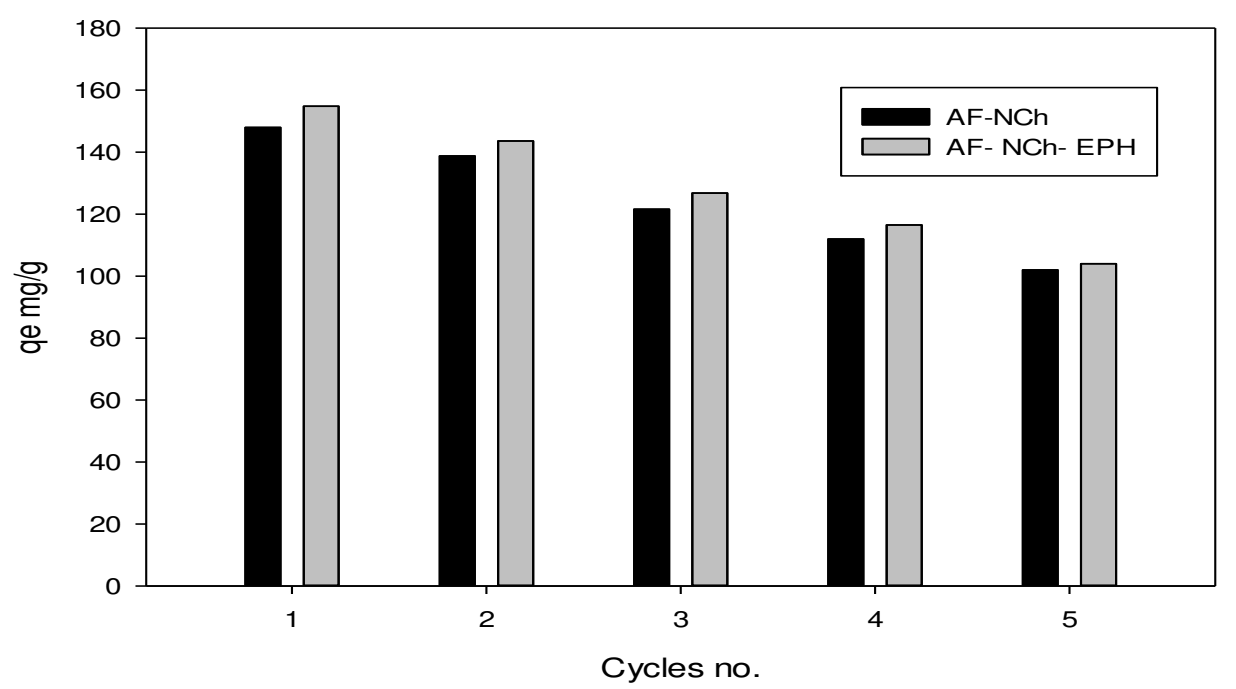

Figure 11 effect of cycles on adsorption capacity for CR dye by AF-NCh and AF-NCh $-\mathrm{EPH}$.

\section{Comparative study}

We have also compared the maximum sorption capacity $\left(\mathrm{q}_{\mathrm{m}}\right)$ for the adsorption of $\mathrm{CR}$ dye onto the prepared nanocomposites with other nanoadsorbents and presented in Table 5. It is observed from the table that the CR dye adsorption capacity of blended $\mathrm{AF} /$ nanochitosan films is higher than the reported nanoadsorbents. Thus the prepared AF- NCh \& AF-NCH-EPH have great potential for CR from aqueous media. 
Table 5: Comparison of adsorption capacities of various adsorbents for removal of CR dye

\begin{tabular}{|l|c|c|c|c|}
\hline Adsorbent & qmax $\mathrm{mg} / \mathrm{g}$ & $\begin{array}{l}\text { Adsorption } \\
\text { isotherm } \\
\text { model }\end{array}$ & $\begin{array}{l}\text { Adsorbate } \\
\text { (Dye) }\end{array}$ & References \\
\hline $\begin{array}{l}\text { PAN-PEI 2D Nano } \\
\text { fibrous mat. }\end{array}$ & 77.5 & Lang. & CR & [57] \\
\hline $\begin{array}{l}\text { Functionalized PAN- } \\
\text { EDA nanofibers }\end{array}$ & 130 & Lang. & CR & [58] \\
\hline $\begin{array}{l}\text { PAN/Fe }{ }_{3} \\
\text { nanocomposite fibers }\end{array}$ & 52 & Lang. & CR & [59] \\
\hline $\begin{array}{l}\text { Chitosan/montmorillonite } \\
\text { nanocomposite }\end{array}$ & 54.2 & Lang. & CR & [60] \\
\hline $\begin{array}{l}\text { AF-NCh } \\
\text { AF- NCh-EPH }\end{array}$ & 166.6 & Lang. & CR & Our study \\
\hline
\end{tabular}

\section{Conclusion}

This work was a trial for utilize acrylic fibers waste to treat waste whereas recycling of (AF) waste into adsorbent films which enhanced via mixing with ecofriendly nanochitosan $(\mathrm{NCh})$ with high ratio. Preparation of nanocomposites films, AF-NCh and AF-NCh-EPH was performed. The nanocomposite films were well characterized via instrumental techniques and evaluated for their removal capability for anionic dye (Congo red) from aqueous solution at a $\mathrm{pH}$ of 5.5. The results indicated the efficiency of the prepared films for removing of CR with maximum adsorption capacities of 166.6 and $232.5 \mathrm{mg} / \mathrm{g}$ for AF-NCh and AF-NCh-EPH, respectively. The adsorption was fitted to Langmuir isotherm and pseudo second order mechanism. The prepared adsorbents showed relative stability after 5 cycles of regeneration.

Conflict of interest: The authors confirm that there is no conflict of interest 


\section{Reference}

[1] C.R. Holkar, A.J. Jadhav, D. V. Pinjari, N.M. Mahamuni, A.B. Pandit, A critical review on textile wastewater treatments: Possible approaches, J. Environ. Manage. 182 (2016). https://doi.org/10.1016/j.jenvman.2016.07.090.

[2] J. Abdi, M. Vossoughi, N.M. Mahmoodi, I. Alemzadeh, Synthesis of metalorganic framework hybrid nanocomposites based on GO and CNT with high adsorption capacity for dye removal, Chem. Eng. J. 326 (2017) 1145-1158. https://doi.org/10.1016/j.cej.2017.06.054.

[3] M.A. Rauf, S. Salman Ashraf, Survey of recent trends in biochemically assisted degradation of dyes, Chem. Eng. J. 209 (2012) 520-530. https://doi.org/10.1016/j.cej.2012.08.015.

[4] J. Wang, L. Qin, J. Lin, J. Zhu, Y. Zhang, J. Liu, B. Van der Bruggen, Enzymatic construction of antibacterial ultrathin membranes for dyes removal, Chem. Eng. J. 323 (2017) 56-63. https://doi.org/10.1016/j.cej.2017.04.089.

[5] Y. Peng, Y. Zhang, H. Huang, C. Zhong, Flexibility induced high-performance MOF-based adsorbent for nitroimidazole antibiotics capture, Chem. Eng. J. 333 (2018) 678-685. https://doi.org/10.1016/j.cej.2017.09.138.

[6] M. Sarro, N.P. Gule, E. Laurenti, R. Gamberini, M.C. Paganini, P.E. Mallon, P. Calza, ZnO-based materials and enzymes hybrid systems as highly efficient catalysts for recalcitrant pollutants abatement, Chem. Eng. J. 334 (2018) 25302538. https://doi.org/10.1016/j.cej.2017.11.146.

[7] L. Tang, J. Yu, Y. Pang, G. Zeng, Y. Deng, J. Wang, X. Ren, S. Ye, B. Peng, H. Feng, Sustainable efficient adsorbent: Alkali-acid modified magnetic biochar derived from sewage sludge for aqueous organic contaminant removal, Chem. Eng. J. 336 (2018) 160-169. https://doi.org/10.1016/j.cej.2017.11.048.

[8] K.A. Adegoke, O.S. Bello, Dye sequestration using agricultural wastes as adsorbents, Water Resour. Ind. 12 (2015) 8-24. https://doi.org/10.1016/j.wri.2015.09.002. 
[9] G. Crini, Non-conventional low-cost adsorbents for dye removal: A review, Bioresour. Technol. 97 (2006) 1061-1085. https://doi.org/10.1016/j.biortech.2005.05.001.

[10] M. Rafatullah, O. Sulaiman, R. Hashim, A. Ahmad, Adsorption of methylene blue on low-cost adsorbents: A review, J. Hazard. Mater. 177 (2010) 70-80. https://doi.org/10.1016/j.jhazmat.2009.12.047.

[11] M.A.M. Salleh, D.K. Mahmoud, W.A.W.A. Karim, A. Idris, Cationic and anionic dye adsorption by agricultural solid wastes: A comprehensive review, Desalination. 280 (2011) 1-13. https://doi.org/10.1016/j.desal.2011.07.019.

[12] A. Srinivasan, T. Viraraghavan, Decolorization of dye wastewaters by biosorbents: A review, J. Environ. Manage. 91 (2010) 1915-1929. https://doi.org/10.1016/j.jenvman.2010.05.003.

[13] N.P. Raval, P.U. Shah, N.K. Shah, Adsorptive amputation of hazardous azo dye Congo red from wastewater: a critical review, Environ. Sci. Pollut. Res. 23 (2016) 14810-14853. https://doi.org/10.1007/s11356-016-6970-0.

[14] J. Shu, Z. Wang, Y. Huang, N. Huang, C. Ren, W. Zhang, Adsorption removal of Congo red from aqueous solution by polyhedral $\mathrm{Cu} 2 \mathrm{O}$ nanoparticles: Kinetics, isotherms, thermodynamics and mechanism analysis, J. Alloys Compd. 633 (2015) 338-346. https://doi.org/10.1016/j.jallcom.2015.02.048.

[15] V.S. Munagapati, D.S. Kim, Adsorption of anionic azo dye Congo Red from aqueous solution by Cationic Modified Orange Peel Powder, J. Mol. Liq. 220 (2016) 540-548. https://doi.org/10.1016/j.molliq.2016.04.119.

[16] S. Rani, R.K. Mahajan, Kinetic and equilibrium studies of adsorption of dye congo red from aqueous solutions on bagasse charcoal and banana peels, J. Surf. Sci. Technol. 28 (2012) 133-147.

[17] Y. Achour, L. Bahsis, E.-H. Ablouh, H. Yazid, M.R. Laamari, M. El Haddad, Insight into adsorption mechanism of Congo red dye onto Bombax Buonopozense bark Activated-carbon using Central composite design and DFT studies, Surfaces and Interfaces. 23 (2021) 100977. 
[18] A. Rajappa, B.A. KR, Kinetics of adsorption of Congo red onto multiwalled nano carbon, Int J Curr Res Chem Pharm Sci. 1 (2014) 18-23.

[19] A. Rajappa, K. Ramesh, V. Nandhakumar, Removal of Congo red dye from aqueous solution using $\mathrm{ZnCl} 2$ activated carbon prepared from Delonix regia pods (flame tree), Int J Chem Pharm Sci. 2 (2014) 961-971.

[20] A. Rajappa, K. Ramesh, V. Nandhakumar, H. Ramesh, Kinetics of Adsorption of Congo Red Dye onto Commercial Activated Carbon from Aqueous Solution, J. Environ. Nanotechnol. 3 (2014) 43-49. https://doi.org/10.13074/jent.2014.03.142067.

[21] A. Rajappa, K. Ramesh, V. Nandhakumar, H. Ramesh, Equilibrium and Isotherm Studies of Congo Red Adsorption Onto Commercial Activated Carbon, Int. J. Curr.Res.Chem.Pharma.Sci. 2 (2015) 51-58.

[22] N.A. Mohamed, N.F. Al-Harby, M.S. Almarshed, Enhancement of adsorption of Congo red dye onto novel antimicrobial trimellitic anhydride isothiocyanatecross-linked chitosan hydrogels, Polym. Bull. 77 (2020) 6135-6160. https://doi.org/10.1007/s00289-019-03058-6.

[23] N.P. Raval, P.U. Shah, D.G. Ladha, P.M. Wadhwani, N.K. Shah, Comparative study of chitin and chitosan beads for the adsorption of hazardous anionic azo dye Congo Red from wastewater, Desalin. Water Treat. 57 (2016) 9247-9262. https://doi.org/10.1080/19443994.2015.1027959.

[24] T. Feng, F. Zhang, J. Wang, Z. Huang, Notice of Retraction: Adsorption of Congo Red by Cross-Linked Chitosan Film, in: 2011 5th Int. Conf. Bioinforma. Biomed. Eng., IEEE, 2011: pp. 1-4.

[25] T.Y. Kim, S.S. Park, S.Y. Cho, Adsorption characteristics of Reactive Black 5 onto chitosan beads cross-linked with epichlorohydrin, J. Ind. Eng. Chem. 18 (2012) 1458-1464. https://doi.org/10.1016/j.jiec.2012.02.006.

[26] W.H. Cheung, Y.S. Szeto, G. McKay, Enhancing the adsorption capacities of acid dyes by chitosan nano particles, Bioresour. Technol. 100 (2009) 11431148. https://doi.org/10.1016/j.biortech.2008.07.071. 
[27] H. Rezaei, A. Razavi, A. Shahbazi, Removal of Congo red from aqueous solutions using nano-chitosan, Environ. Resour. Res. 5 (2017) 25-34.

[28] Y. Yulizar, T. Utari, D.O.B. Apriandanu, Y.R.P. Putri, Chitosan nanoparticles on a natural zeolite as an efficient adsorbent for Congo red, IOP Conf. Ser. Mater. Sci. Eng. 496 (2019). https://doi.org/10.1088/1757-899X/496/1/012005.

[29] S. Chatterjee, T. Chatterjee, S.H. Woo, A new type of chitosan hydrogel sorbent generated by anionic surfactant gelation, Bioresour. Technol. 101 (2010) 38533858. https://doi.org/10.1016/j.biortech.2009.12.089.

[30] I. Ali, New generation adsorbents for water treatment, Chem. Rev. 112 (2012) 5073-5091. https://doi.org/10.1021/cr300133d.

[31] R. Jiang, J. Yao, H. Zhu, Y. Fu, Y. Guan, L. Xiao, G. Zeng, Effective decolorization of congo red in aqueous solution by adsorption and photocatalysis using novel magnetic alginate $/ \gamma$ - $\mathrm{Fe} 2 \mathrm{O} 3 / \mathrm{CdS}$ nanocomposite, Desalin. Water Treat. 52 (2014) 238-247. https://doi.org/10.1080/19443994.2013.787551.

[32] H. Hou, R. Zhou, P. Wu, L. Wu, Removal of Congo red dye from aqueous solution with hydroxyapatite/chitosan composite, Chem. Eng. J. 211-212 (2012) 336-342. https://doi.org/10.1016/j.cej.2012.09.100.

[33] Q. Du, J. Sun, Y. Li, X. Yang, X. Wang, Z. Wang, L. Xia, Highly enhanced adsorption of congo red onto graphene oxide/chitosan fibers by wet-chemical etching off silica nanoparticles, Chem. Eng. J. 245 (2014) 99-106. https://doi.org/10.1016/j.cej.2014.02.006.

[34] A. Yunessnia lehi, A. Akbari, Novel membrane adsorbents prepared by waste fibers of mechanized carpet for Persian Orange X removal, Environ. Nanotechnology, Monit. Manag. 8 (2017) 209-218. https://doi.org/10.1016/j.enmm.2017.08.004.

[35] M. Chen, C. Wang, W. Fang, J. Wang, W. Zhang, G. Jin, G. Diao, Electrospinning of calixarene-functionalized polyacrylonitrile nanofiber membranes and application as an adsorbent and catalyst support, Langmuir. 29 
(2013) 11858-11867. https://doi.org/10.1021/la4017799.

[36] S.A. Jadoo, J.A. Naser, Adsorption Optimization of Congo Red Dye onto Electrospun Nanofibers of Polyacrylonitrile functionalized with Fe3O4Nanoparticles, IOP Conf. Ser. Mater. Sci. Eng. 928 (2020). https://doi.org/10.1088/1757-899X/928/5/052024.

[37] S.A. Jadoo, J.A. Naser, Adsorption thermodynamic study of Congo red dye on electrospun nanofibers mat of polyacrylonitrile, J. Glob. Pharma Technol. 11 (2019) 401-411.

[38] A. Labena, A.E. Abdelhamid, S. Husien, T. Youssef, E. Azab, A.A. Gobouri, G. Safwat, Grafting of acrylic membrane prepared from fibers waste for dyes removal: Methylene blue and congo red, Separations. 8 (2021). https://doi.org/10.3390/separations8040042.

[39] A.H. Orabi, A.E.S. Abdelhamid, H.M. Salem, D.A. Ismaiel, New adsorptive composite membrane from recycled acrylic fibers and Sargassum dentifolium marine algae for uranium and thorium removal from liquid waste solution, $\mathrm{J}$. Radioanal. Nucl. Chem. 326 (2020) 1233-1247. https://doi.org/10.1007/s10967020-07403-2.

[40] C. Govindarajan, S. Ramasubramaniam, T. Gomathi, A.N. Devi, P.N. Sudha, Sorption studies of $\mathrm{Cr}$ ( VI ) from aqueous solution using nanochitosancarboxymethyl cellulose blend, Arch. Appl. Sci. Res. 2011, 3 (4)127-138. 3 (2011) 127-138.

[41] M.H. Dehghani, A. Dehghan, A. Najafpoor, Removing Reactive Red 120 and 196 using chitosan/zeolite composite from aqueous solutions: Kinetics, isotherms, and process optimization, The Korean Society of Industrial and Engineering Chemistry, 2017. https://doi.org/10.1016/j.jiec.2017.03.001.

[42] N.F. El-Harby, S.M.A. Ibrahim, N.A. Mohamed, Adsorption of Congo red dye onto antimicrobial terephthaloyl thiourea cross-linked chitosan hydrogels, Water Sci. Technol. 76 (2017) 2719-2732. https://doi.org/10.2166/wst.2017.442. 
[43] D. Kołodyńska, P. Hałas, M. Franus, Z. Hubicki, Zeolite properties improvement by chitosan modification-Sorption studies, J. Ind. Eng. Chem. 52 (2017) 187-196. https://doi.org/10.1016/j.jiec.2017.03.043.

[44] M.A.A. El-Ghaffar, M.M. Elawady, A.M. Rabie, A.E. Abdelhamid, Enhancing the RO performance of cellulose acetate membrane using chitosan nanoparticles, J. Polym. Res. 27 (2020) 337. https://doi.org/10.1007/s10965020-02319-7.

[45] P.A. Vinodhini, K. Sangeetha, T. Gomathi, P.N. Sudha, J. Venkatesan, S. Anil, FTIR, XRD and DSC Studies of Nanochitosan, Cellulose acetate and Polyethylene glycol Blend Ultrafiltration Membranes, Int. J. Biol. Macromol. (2017). https://doi.org/10.1016/j.ijbiomac.2017.03.122.

[46] A. Ghadi, S. Mahjoub, F. Tabandeh, F. Talebnia, Synthesis and optimization of chitosan nanoparticles: Potential applications in nanomedicine and biomedical engineering, Casp. J. Intern. Med. 5 (2014) 156-161.

[47] M.C. Grieve, Another look at the classification of acrylic fibres, using FTIR microscopy, Sci. Justice. 35 (1995) 179-190.

[48] S. Salehi, M. Hosseinifard, Optimized removal of phosphate and nitrate from aqueous media using zirconium functionalized nanochitosan-graphene oxide composite, Cellulose. 27 (2020) 8859-8883. https://doi.org/10.1007/s10570020-03382-5.

[49] S.P. Campana Filho, Thermal behavior of cross-linked carboxymethylchitosan membranes, Brazilian J. Therm. Anal. 4 (2015) 70. https://doi.org/10.18362/bjta.v4.i4.233.

[50] V. Sharma, P. Rekha, P. Mohanty, Nanoporous hypercrosslinked polyaniline: An efficient adsorbent for the adsorptive removal of cationic and anionic dyes, J. Mol. Liq. 222 (2016) 1091-1100. https://doi.org/10.1016/j.molliq.2016.07.130.

[51] F. Piri, A. Mollahosseini, A. Khadir, M. Milani Hosseini, Enhanced adsorption of dyes on microwave-assisted synthesized magnetic zeolite-hydroxyapatite 
nanocomposite, J. Environ. Chem. Eng. 7 (2019) 103338.

https://doi.org/10.1016/j.jece.2019.103338.

[52] K.T. Kubra, M.S. Salman, M.N. Hasan, Enhanced toxic dye removal from wastewater using biodegradable polymeric natural adsorbent, J. Mol. Liq. 328 (2021) 115468.

[53] A.H. Jawad, A.S. Abdulhameed, A. Reghioua, Z.M. Yaseen, Zwitterion composite chitosan-epichlorohydrin/zeolite for adsorption of methylene blue and reactive red 120 dyes, Int. J. Biol. Macromol. 163 (2020) 756-765. https://doi.org/10.1016/j.ijbiomac.2020.07.014.

[54] S. Saadat, A. Karimi-Jashni, Optimization of $\mathrm{Pb}(\mathrm{II})$ adsorption onto modified walnut shells using factorial design and simplex methodologies, Chem. Eng. J. 173 (2011) 743-749. https://doi.org/10.1016/j.cej.2011.08.042.

[55] M. Saad, H. Tahir, D. Ali, Green synthesis of Ag-Cr-AC nanocomposites by Azadirachta indica and its application for the simultaneous removal of binary mixture of dyes by ultrasonicated assisted adsorption process using Response Surface Methodology, Ultrason. Sonochem. 38 (2017) 197-213. https://doi.org/10.1016/j.ultsonch.2017.03.022.

[56] S. Chatterjee, T. Chatterjee, S.R. Lim, S.H. Woo, Effect of the addition mode of carbon nanotubes for the production of chitosan hydrogel core-shell beads on adsorption of Congo red from aqueous solution, Bioresour. Technol. 102 (2011) 4402-4409. https://doi.org/10.1016/j.biortech.2010.12.117.

[57] R.K. Sadasivam, S. Mohiyuddin, G. Packirisamy, Electrospun polyacrylonitrile (PAN) Templated 2D Nanofibrous Mats: A platform toward practical applications for dye removal and bacterial disinfection, ACS Omega. 2 (2017) 6556-6569. https://doi.org/10.1021/acsomega.7b01101.

[58] S. Patel, G. Hota, Synthesis of novel surface functionalized electrospun PAN nanofibers matrix for efficient adsorption of anionic CR dye from water, $\mathrm{J}$. Environ. Chem. Eng. 6 (2018) 5301-5310. https://doi.org/10.1016/j.jece.2018.08.013. 
[59] V.A. Online, RSC Advances, (2016). https://doi.org/10.1039/C5RA20345G.

[60] L. Wang, A. Wang, Adsorption characteristics of Congo Red onto the chitosan / montmorillonite nanocomposite, 147 (2007) 979-985.

https://doi.org/10.1016/j.jhazmat.2007.01.145. 